\title{
MATERNAL SERUM CALCIUM AND TRACE ELMENTS; COPPER AND ZINC AMONG PRE-ECLAMPTIC WOMEN IN CAIRO, EGYPT
}

\author{
Essam A. El-Moselhy, Hesham H. Amin*, Hani M. Abd El-Aal** \\ Departments of Community Medicine, \\ Clinical Pathology* and Obstetric \& Gynecology** \\ Faculty of Medicine, Al-Azhar University
}

\begin{abstract}
Introduction: Low levels of blood calcium $(\mathrm{Ca})$ and trace elements are observed in patients with pre-eclampsia (PE). Among these patients low serum $\mathrm{Ca}$, copper $(\mathrm{Cu})$ and zinc $(\mathrm{Zn})$ may be one of the disease causes. Objectives: The aim of this study was to find out the serum biochemical profile of these elements in the studied pre-eclamptic women. Subjects and methods: A casecontrol, hospital based study design was used. All the cases and controls were examined laboratory. Results: Maternal mean serum $\mathrm{Ca}, \mathrm{Cu}$ and $\mathrm{Zn}$ were lower among pre-eclamptic cases compared to normal pregnant controls with statistically significant differences $(\mathrm{P}=0.000$ for each of them). Further, maternal mean serum $\mathrm{Ca}, \mathrm{Cu}$ and $\mathrm{Zn}$ were lower among the severe $\mathrm{PE}$ cases compared to the mild cases with statistically significant differences $(\mathrm{P}=0.002,0.000$ and 0.000 , respectively). Also, these low elements; $\mathrm{Ca}, \mathrm{Cu}$ and $\mathrm{Zn}$ were significantly correlated factors with severe PE ( $\mathrm{P}=0.01,0.03$ and 0.01 , respectively). Recommendations: Early ante-natal care and treatment for pre-eclamptic women are recommended. $\mathrm{Ca}, \mathrm{Cu}$ and $\mathrm{Zn}$ supplementation may be a cost effective method to prevent PE. Prospective population based studies are needed in different areas in Egypt and on large number of pregnant women to determine possible PE risk factors.
\end{abstract}

\section{Introduction}

Hypertension associated with pregnancy is the most common medical risk factor for maternal morbidity and mortality (Ventura et al., 2000). Further, preeclampsia (PE) can progress rapidly; putting mother at severe risk if there is no good management (Basso et al., 2006). Although $\mathrm{PE}$ is an important cause of maternal and fetal morbidity and mortality, its etiology is still under investigation (Solmon \& Seely, 2004 and Ziaei et al., 2006).

The role of antioxidants in the prevention of PE is still unresolved issues (Jeyabalan and Caritis, 2006). Some studies have concluded that changes in levels of blood elements are observed in patients with PE (James et al., 2006). On the other hand, other studies have failed to show an association between the serum concentrations of these elements and occurrence of PE (Cunningham et al., 2010).

$\mathrm{PE}$ is a complex disorder caused by a series of genetic, nutritional and environmental factors that lead to the creation of an imbalance between the free radicals; nitric oxide (NO), superoxide $\left(\mathrm{O}_{2}{ }^{-}\right)$ and peroxynitrate in the vascular endothelium (López-Jaramillo, 2000). In normal pregnancy the processes of implantation, proliferation, differentiation and trophoplast invasion produce reactive oxygen species (ROS). However, in PE lipid peroxidation, which also yields ROS, in form of free oxygen radicals, is uncontrolled. It is speculated that pregnancy will progress uneventfully if adequate antioxidants exist to buffer ROS (Caniggia et al., 2000 and Rumiris et al., 2006). Also, 
$\mathrm{PE}$ is associated with an imbalance of increase lipid peroxides and decreased antioxidants (Ziaei et al., 2006). Placental oxidative stress (OS) has been shown to be a key feature in the pathogenesis of PE. OS is an imbalance between the cellular generation of ROS and the capacity of antioxidants to prevent oxidative damage. The expression and activity of important antioxidant proteins are decreased in placental tissues from the pre-eclamptic women, resulting in an imbalance between pro oxidants and antioxidants leading to OS (Walsh, 1998).

Antioxidant nutrient levels can be manipulated simply by dietary or pharmacological supplements (Mikhail et al., 1994). High rate of $P E$ in developing countries have forced some authors to conclude that malnutrition is a risk factor in the etiology of PE and implicate it by deficit intake of calcium (Ca) and zinc ( $\mathrm{Zn})$ (Caughey et al., 2005). Also, nutrition deficiencies considered risk factors of PE in developed countries (Roberts et al., 2003). Among these deficiencies are $\mathrm{Ca}$ and trace elements; $\mathrm{Zn}$ and copper $(\mathrm{Cu})$. The suggested importance of the deficiencies of trace elements in PE relates to the fact that they are present in metallothionein (zinc), ceruloplasmin (copper), superoxide dismutase (copper, selenium (Se), zinc) and glutathione peroxidase (Se). Conversely, $\mathrm{Cu}$ as a transition element can catalyze the formation of free radicals. Several studies of zinc in PE are reviewed, but little information is available on the other trace elements (Borella et al., 2001). Further, the suggested importance of the deficiencies of trace elements in PE relates to the fact that they are present in superoxide dismisses (copper, selenium and zinc) and glutathione peroxidase (GSH-Px) (Se). Also, messenger RNA expression for copper-zinc-superoxide dismisses and glutathione peroxidase is lower in pre-eclamptic placenta (Wang and Walsh, 1996; Mahomed et al., 2000 and Rayman, 2000).

Antioxidants are relatively cheap to produce and, if future large studies prove that they are beneficial, they may be important for mothers in developing countries that have a high risk of morbidity and mortality associated with PE (Rumiris et al., 2006). Daily supplementation with
1.5-2 gm calcium is the only known effective way of non-medical prevention of PE. But, because of the large dose of calcium, it may be better to restrict prophylaxis to women at high risk of $\mathrm{PE}$ (Ehrenberg, 1997). Also, maternal zinc deficiency is increasingly suggested as a possible public health problem. It has been associated in some epidemiological studies with reduced fetal growth and neurobehavioral development, preterm labor and labor complications. Further, it was suggested to affect other postnatal outcomes such as immunological development, vitamin A status and postnatal growth (Caulfled et al., 1998).

\section{Study objectives}

1- To find out mean levels of serum $\mathrm{Ca}, \mathrm{Cu}$ and $\mathrm{Zn}$ among the pre-eclamptic mothers in Cairo, Egypt.

2- To determine the profile of these elements among mild and severe preeclamptic mothers in Cairo, Egypt.

\section{Subjects and methods}

I- Study Questions: Is there maternal serum deficiencies of calcium, and trace elements; copper and zinc in the preeclamptic women? Is there correlation between these biochemical markers and severity of PE?

II- Study Design: A case-control, hospital based design was used to investigate the current research problem.

III- Study Setting: This study was conducted in the Obstetric and Gynecology Department in Al-Hussein Hospital, AlAzhar University.

IV- Study Sample: According to sample size equation the sample was 86 cases and to guard against sample size bias we increased the sample to be $100 \mathrm{PE}$ cases. So, all the cases of PE attending the Obstetric and Gynecology Department, Al-Hussein Hospital, Al-Azhar University were included in the study tell sample reached the required number; 100. For each preeclamptic patient a healthy pregnant woman 
was chosen randomly. So, a control group of 100 healthy pregnant women was recruited.

All patients must be fulfilling the following inclusion criteria: 1) Age of patients up to 30 years, 2) Gestational age $\geq 33$ weeks, 3) Have a definite specific diagnosis of PE. Also, all patients recruited in this study have fulfilled the following specific exclusion criteria: 1) Essential hypertension, 2) Pregnancy induced hypertension without proteinuria, 3) Intake of vitamins/antioxidants during the current pregnancy, 4) Blood diseases, 5) Kidney disease, 6) Liver disease, 7) Intrauterine fetal death, and 8) Ante-partum hemorrhage.

The controls enrolled in the study have fulfilled the following inclusion criteria: 1) Age up to 30 years, 2) Have no history of PE in the current or previous pregnancy, and 3) Gestational age $\geq 33$ weeks. Also, the controls have fulfilled the same specific exclusion criteria used for the patients group.

V- Ethical Consideration: The purpose of the study and procedures to be performed were explained to the cases and controls, an oral consent to participate in the study was taken accordingly. All patients were managed properly to control PE. All the cases and controls were delivered spontaneously in the normal vertex position or by Caesarian section according to the condition of each case.

\section{VI- Study Tools and Methods:}

1- Diagnosis of PE: All patients must be fulfilling the following inclusion criteria: 1) Hypertension: Blood pressure (BP) $\geq 140 / 90 \mathrm{mmHg}$, 2) Proteinuria: Trace or more by dipstick method, and 3) Bilateral lower limb edema: $\geq+1$.

Pregnancy-induced hypertension was defined as $\mathrm{BP} \geq 140 / 90 \mathrm{mmHg}$ (mild $\mathrm{PE}$ ) and $\mathrm{BP} \geq 160 / 110 \mathrm{mmHg}$ (severe PE) (National Education program Working Group on High Blood Pressure, 2000). Proteinuria, trace to +1 (mild PE) and $\geq+2$ (severe PE). Two random midstream urine specimens, collected $\geq 4$ hours apart taken from each woman to avoid error due to false positive tests, were used for detection of proteinuria. The two results must be positive, so the diagnosis of proteinuria was significant (MacGillivary, 1983). Edema is a common feature of pregnancy, but edema of PE is pathological and not just dependant; it usually involves the face, hands and persists even after arising (Cunningham et al., 2010).

2- Laboratory investigations: Laboratory examinations were done for all cases and controls. Fasting venous blood samples, 5 $\mathrm{ml}$, were taken for lab examinations. These examinations were done to estimate total serum $\mathrm{Ca}, \mathrm{Cu}$ and $\mathrm{Zn}$.

Total serum Ca level (mg/dl) was determined by colorimetric method using $\mathrm{O}$ Cresophthalein complexone without deproteinization (Lorenz, 1982). Also, determination of serum $\mathrm{Cu}(\mu \mathrm{g} / \mathrm{dl})$ and $\mathrm{Zn}$ $(\mu \mathrm{g} / \mathrm{dl})$ were done by using flameless atomic absorption spectrophotometer (460) graphite unit (200). Copper was determined according to Mason (1979), while Zinc was determined according to Sunderman (1973).

VII- Data Analysis: Unpaired t student test and correlation co-efficient were used as tests of significance. The significance level was accepted if the P-value $<0.05$.

\section{Results}

As regard the laboratory results of maternal serum calcium and trace elements biochemical markers among the PE cases and control group (table 1), the mean and standard deviation values of serum Ca levels among total PE cases and controls were $7.10 \pm 1.28$ and $8.17 \pm 2.09 \mathrm{mg} / \mathrm{dl}$, respectively with a statistically significant difference $(\mathrm{P}=0.000)$. Also, the mean and standard deviation values of serum $\mathrm{Ca}$ levels among mild PE cases and controls were $7.63 \pm 1.27$ and $8.17 \pm 2.09 \mathrm{mg} / \mathrm{dl}$, respectively with a statistically significant difference $(\mathrm{P}=0.02)$. Lastly, the mean and standard deviation values of serum Ca levels among severe PE cases and controls were $6.81 \pm 1.12$ and $8.17 \pm 2.09 \mathrm{mg} / \mathrm{dl}$, respectively with a statistically significant difference $(\mathrm{P}=0.000)$. At the same time, the mean and standard deviation values of serum $\mathrm{Cu}$ levels among total PE cases and controls were $62.91 \pm 9.81$ and $96.72 \pm 11.90$ $\mu \mathrm{g} / \mathrm{dl}$, respectively with a statistically significant difference $(\mathrm{P}=0.000)$. Also, the 
mean and standard deviation values of serum $\mathrm{Cu}$ levels among mild PE cases and controls were $71.13 \pm 10.72$ and $96.72 \pm 11.90$ $\mu \mathrm{g} / \mathrm{dl}$, respectively with a statistically significant difference $(\mathrm{P}=0.000)$. Lastly, the mean and standard deviation values of serum $\mathrm{Cu}$ levels among severe PE cases and controls were $54.74 \pm 8.76$ and $96.72 \pm 11.90$ $\mu \mathrm{g} / \mathrm{dl}$, respectively with a statistically significant difference $(\mathrm{P}=0.000)$. Moreover, the mean and standard deviation values of serum $\mathrm{Zn}$ levels among total PE cases and controls were $60.81 \pm 9.74$ and $95.70 \pm 12.41$ $\mu \mathrm{g} / \mathrm{dl}$, respectively with a statistically significant difference $(\mathrm{P}=0.000)$. Also, the mean and standard deviation values of serum Zn levels among mild PE cases and controls were $68.43 \pm 10.91$ and $95.70 \pm 12.41$ $\mu \mathrm{g} / \mathrm{dl}$, respectively with a statistically significant difference $(\mathrm{P}=0.000)$. Lastly, the mean and standard deviation values of serum $\mathrm{Zn}$ levels among severe PE cases and controls were 53.21 \pm 9.10 and $95.70 \pm 12.41$ $\mu \mathrm{g} / \mathrm{dl}$, respectively with a statistically significant difference $(\mathrm{P}=0.000)$.

Regarding results of maternal mean serum calcium and trace elements biochemical markers among the PE cases according to severity (table 2), the mean and standard deviation values of serum $\mathrm{Ca}$ levels among mild and severe PE cases were $7.63 \pm 1.27$ and $6.81 \pm 1.12 \mathrm{mg} / \mathrm{dl}$, respectively with a statistically significant difference $(\mathrm{P}=0.002)$. Also, the mean and standard deviation values of serum $\mathrm{Cu}$ levels among mild and severe PE were $71.13 \pm 10.72$ and $54.74 \pm 8.76 \mu \mathrm{g} / \mathrm{dl}$, respectively with a statistically significant difference $(\mathrm{P}=0.000)$. At the same time, the mean and standard deviation values of serum $\mathrm{Zn}$ levels among mild and severe PE cases were $68.43 \pm 10.91$ and $53.21 \pm 9.10$ $\mu \mathrm{g} / \mathrm{dl}$, respectively with a statistically significant difference $(\mathrm{P}=0.000)$.

Respecting the correlation coefficient of severe PE according to significant findings of the laboratory examinations of maternal mean serum calcium and trace elements (table 3), low levels of mean serum $\mathrm{Ca}, \mathrm{Cu}$ and $\mathrm{Zn}$ were significantly correlated with severe $\mathrm{PE}$ ( $\mathrm{P}=0.01,0.03$ and 0.01 , respectively).

\section{Discussion}

The scarcity of studies concerning maternal trace elements status during pregnancy and the inconstant findings from the published studies, led us to decide to assess; in the present case-control, hospital based study; the maternal mean serum levels of $\mathrm{Ca}, \mathrm{Zn}$ and $\mathrm{Cu}$ in pregnant women with PE in Egypt.

Nutritional deficiencies of both macro- and micro-nutrients are common in women of reproductive age in developing countries. Epidemiological and biological evidence suggest that acute or chronic nutritional deficiencies can contribute to severe maternal morbidity (Rayman et al., 1996 and Ziaei et al., 2006). Further, there are suggestions that macro- or micronutrients may modify the inflammatory response (Powers et al., 1998).

Significant changes in serum trace element concentrations; particularly $\mathrm{Zn}$ and $\mathrm{Cu}$ have been documented during normal pregnancies (Ilhan et al., 2002). Trace elements, because of their biological role as catalysts for endogenous antioxidant enzymes, have been the subject of clinical research designed to assess the etiology of PE (Gromadzinska et al., 1998) and other adverse reproductive outcomes (Borella et al., 2001). Oxidative stress (OS) is proposed as the linkage of the two stages of PE (Roberts and Hubel, 1999 and Mahomed et al., 2000). Also, because of their role in catalysts; $\mathrm{Zn}$ and $\mathrm{Cu}$ are components of numerous metalloenzymes and cofactors for super dismutase enzyme (Mahomed et al., 2000). Nutrients can affect OS by increasing or decreasing free radicals or antioxidants or by providing substrate for the formation of free radicals. Lipids are, also, extensively involved in the generations of free radicals (Witztum, 1994 and LaMarca et al., 2008).

Calcium is the micronutrient that has been best studied in relationship to PE. Its deficiency has been associated with PE. Further, calcium dietary deficiency has been proposed as a possible cause of PE (Levine et al., 1997). But, the results of $\mathrm{Ca}$ supplementation to prevent hypertension during pregnancy are inconsistent (Villar et al., 2003). In numerous controlled studies, oral calcium supplementation has been 
studied as a possible preventive measure for PE (Moutquin et al., 1997). While, most of the studies found a significant reduction in the incidence of PE (Crowther et al., 1999), some reported no change (Levine et al., 1997). Also, several epidemiological studies in developing nations indicate an association between reduced calcium intake and PE (Belizan \& Villar, 1980 and Belizan et al., 1983). This observation led to the hypothesis that the incidence of PE can be reduced in populations of low Ca intake by Ca supplementation (Belizan et al., 1988). Also, in developed countries, oral $\mathrm{Ca}$ supplementation has been studied as a possible preventive measure for PE (Moutquin et al., 1997 and Crowther et al., 1999). $P E$ is associated with hypocalcuria. A urinary calcium concentration equal to or less than $12 \mathrm{mg} / \mathrm{dl}$ in a 24 hour collection has positive and negative predictive values of $85.0 \%$ and $91.0 \%$, respectively, for the diagnosis of PE. As this phenomenon occurs early and persists throughout gestation, being potentially useful for the early identification of patients at risk (Sanchez-Ramos et al., 1991).

Maternal serum $\mathrm{Ca}$ level is significantly lower in PE women compared to healthy controls (Kumru et al., 2003). Also, maternal serum $\mathrm{Ca}$ level is lower in PE women $(8.70 \pm 0.58 \mathrm{mg} / \mathrm{dl})$ compared to healthy controls $(8.97 \pm 0.49 \mathrm{mg} / \mathrm{dl})$, but with an insignificant difference (Lou et al., 2008). Further, there is marginal evidence that parathyroid or parathyroid like hormone, which increase Ca uptake by cells, may be secreted in larger amounts in PE, but there is little to suggest that this is an important step in the pathogenesis of the disease (Pipkin et al., 1996). The low calcium level may be explained by an impaired absorption or defective renal handling of calcium (Belizan \& Villar, 1980 and Belizan et al., 1983) or by a low dietary intake among lower social class because of low educational status, poverty and/or pregnancy hyper emesis. So, supplementation with $\mathrm{Ca}(600 \mathrm{mg} /$ day $)$ and linoleic acid (450 mg/day), in a double blind study, during the third trimester of pregnancy significantly reduced the incidence of $\mathrm{PE}$ in women at high risk, possibly by correction of the PGE2 levels
(Herrera et al., 1998). Also, supplementation with $1800 \mathrm{mg}$ of $\mathrm{Ca} / \mathrm{day}$, from before the 24th week of pregnancy until delivery, significantly reduced the incidence of PE (Crowther et al., 1999). Further, the Cochrane review of 11 studies performed in 6894 women indicated a $32.0 \%$ reduction of the incidence of PE with $\mathrm{Ca}$ supplementation. This effect was most evident in groups with low baseline $\mathrm{Ca}$ intake (Atallah et al., 2002). Other trials of Ca supplementation that have been based on a relatively large, $2 \mathrm{gm} /$ day, pharmaceutical dose of $\mathrm{Ca}$ (the exception needs $1.5 \mathrm{gm} /$ day). The trials all involved primigravidae women of no apparent additional risk. Metaanalysis shows a modest but satisfactory high significant reduction in the risk of PE. But, there is no enough information for any conclusions about the effect on prenatal morbidity (Bower, 2003). Further, blood $\mathrm{Ca}$ has a relaxant effect on the blood vessels of pregnant women (Skjaerven et al., 2002). So, calcium supplementation during pregnancy leads to an important reduction in systolic and diastolic blood pressure, and PE. While pregnant women at risk of PE should consider taking $\mathrm{Ca}$ many more patients' events are needed to confirm $\mathrm{Ca}$ impact on maternal and fetal morbidity (Bucher et al., 1996).

On the other hand, there was no difference in calcium intake between preeclamptic pregnant women and controls (Levine et al., 1997 and Morris et al., 2001). Further, there is no significant relationship between serum $\mathrm{Ca}$ level and gestational hypertension. So, there might be no clinical participation of $\mathrm{Ca}$ in the pathogenesis of gestational hypertension (Levine et al., 1997 and Magri et al., 2003). Also, in Egypt there was no difference in calcium intake between preeclamptic pregnant women and controls (Mahaba et al., 2001).

Low plasma zinc concentrations have been reported to correlate with many pregnancy complications such as hypertension, spontaneous abortion, prolonged labor, postpartum hemorrhage and congenital malformations (Villar et al., 2003). Moreover, deficiency in placental $\mathrm{Zn}$, also, plays a role in the biosynthesis of connective tissue, maintaining its integrity, which might have an impact on the structure 
of the spiral arteries (Acikgoz et al., 2006). Also, an association between $\mathrm{Zn}$ and PE has been suggested by reduced $\mathrm{Zn}$ concentrations in women with PE compared to pregnant controls (Chisolm and Handorf, 1985; Lazebnik et al., 1989; Ilhan et al., 2002 and Kolusari et al., 2008).

In PE, decreased maternal serum zinc levels have been suggested to be at least partially due to reduced estrogen and $\mathrm{Zn}$ binding protein level (Bassiouni et al., 1979), also serum cortisol level increases during normal pregnancy and much more high in PE, which again reduce maternal zinc level (Kiilholma et al., 1984). Also, Zn deficiency in the placental tissue might cause insufficiency of superoxide dismutase, which is an antioxidant enzyme (Acikgoz et al., 2006).

The consequences of zinc deficiency appear near the middle of pregnancy (Kiilholma et al., 1984 and Adam et al., 2001). Women with $\mathrm{PE}$ as compared with normotensive pregnant women had lower zinc concentrations (Chisolm and Handorf, 1985). Plasma or serum $\mathrm{Zn}$ concentrations have been reported to be lower in pre-eclamptic women (Cherry et al., 1988\&1989). Further, maternal serum $\mathrm{Zn}$ level is lower in PE women compared to healthy controls (Kumru et al., 2003). The mean serum zinc concentration in pre-eclamptic women was $82.94 \pm 28.93 \mathrm{mg} / \mathrm{dl}$ and in normal pregnant $125.19 \pm 24.23 \mathrm{mg} / \mathrm{dl}$ and the difference between the two groups was statistically significant $(\mathrm{P}<0.001)$ (Ilhan et al., 2002). Moreover, the mean serum $\mathrm{Zn}$ concentration in pre-eclamptic group was $0.79 \pm 0.18 \mathrm{mg} / \mathrm{dl}$ vs. $1.08 \pm 0.19 \mathrm{mg} / \mathrm{dl}$ in healthy pregnant. The difference between the groups was statistically insignificant $(\mathrm{P}>0.05)$. But when compared with the non pregnant women the difference was statistically significant $(\mathrm{P}<0.001)$ (Atmar et al., 2005). Also, serum $\mathrm{Zn}$ levels have been reported to be significantly lower in pre-eclamptic women $(1.06 \pm 0.44 \mu \mathrm{g} / \mathrm{dl})$ as compared with normotensive pregnant women $(1.27 \pm 0.41$ $\mu \mathrm{g} / \mathrm{dl})$ and healthy non pregnant women $(1.88 \pm 0.40 \mu \mathrm{g} / \mathrm{dl})$ (Kolusari et al., 2008). At the same time, maternal serum $\mathrm{Zn}$ level is insignificantly lowers in PE women $(12.91 \pm 3.01 \mathrm{mg} / \mathrm{dl})$ compared to healthy controls $(13.07 \pm 3.20 \mathrm{mg} / \mathrm{dl}$ ) (Lou et al., 2008). Further, $\mathrm{Zn}$ level was lower in placental tissues of pre-eclamptic women compared with healthy pregnant women and there was a negative correlation between angiotensin-converting enzyme activity and $\mathrm{Zn}$ concentration (Acikgoz et al., 2006).

On the other hand, not all researchers agree that maternal $\mathrm{Zn}$ decreased during pregnancy (Prema, 1980; Mahomed et al., 2000; Borella et al., 2001 and Ajayi, 2002). The median leukocytic concentration of zinc is $31.0 \%$ higher in preeclamptic than controls (Mahomed et al., 2000). Also, Borella et al. (2001) reported that PE cases had a higher mean plasma concentration of $\mathrm{Zn}$ compared with controls, although this difference did not reach statistical significance $(10.49 \pm 2.28$ vs. $9.60 \pm 2.29 \mu \mathrm{g} / \mathrm{L}, \mathrm{P}>0.05)$. Further, Ajayi (2002) in a study of Nigerian pregnant women showed that mean third-trimester plasma zinc concentrations was higher among women with PE compared with controls $(14.2 \pm 3.71$ vs. $10.1 \pm 0.44 \mu \mathrm{g} / \mathrm{L})$. So, there is no significant relationship between serum $\mathrm{Zn}$ level and gestational hypertension. Further, there might be no clinical participation of $\mathrm{Zn}$ in the pathogenesis of gestational hypertension (Magri et al., 2003).

Further, attempts to modify the frequency of pre-eclampsia with zinc supplementation have not been successful (Hunt et al., 1985). But, because zinc supplementation has adverse effects on copper metabolism, it is recommends that an appropriate copper supplement $(2 \mathrm{mg})$ should accompany zinc supplement use (Mahomed et al., 2000).

Serum copper level increases from about $80-155 \mathrm{mg} / \mathrm{dl}$ before pregnancy to about $118-302 \mathrm{mg} / \mathrm{dl}$ by the end of the third trimester. The physiological increase in copper concentration in pregnancy is, in part, associated estrogen induction of $\mathrm{Cu}$ carrying protein. But, there is considerable inconsistency regarding the results concerning the relation between maternal copper concentrations and occurrence of $\mathrm{PE}$ (Ilhan et al., 2002; Aksoy et al., 2003; Kumru et al., 2003; Atmar et al., 2005 and Harma et al., 2005).

On one hand, some studies have cleared that serum $\mathrm{Cu}$ level is elevated in $\mathrm{PE}$ 
(Zhao et al., 1989; Borella et al., 2001; Serdar et al., 2006; Kolusari et al., 2008 and Ziaei et al., 2008). The mean maternal plasma $\mathrm{Cu}$ concentration was $28 \%$ higher in pre-eclamptic women compared with controls $(51.78 \pm 19.16$ vs. $40.34 \pm 8.85 \mu \mathrm{g} / \mathrm{L}$, $\mathrm{P}<0.001)$ (Borella et al., 2001). Also, the mean $\mathrm{Cu}$ in 24-hour maternal urine was higher in pre-eclamptic women compared with controls $(12.2 \pm 3.7$ vs. $5.7 \pm 2.1 \mathrm{mg} / \mathrm{L}$, $\mathrm{P}<0.001$ ) (Ziaei et al., 2008). At the same time, the mean maternal serum $\mathrm{Cu}$ concentration was higher in pre-eclamptic women compared with controls $(2.65 \pm 0.76$ vs. $2.08 \pm 0.46 \mu \mathrm{g} / \mathrm{dl}, \mathrm{P}<0.05$ ) (Kolusari et al., 2008). But, maternal serum $\mathrm{Cu}$ level was insignificantly higher in women with $\mathrm{PE}$ $(21.40 \pm 2.32 \mathrm{mg} / \mathrm{dl})$ compared to healthy controls $(21.00 \pm 2.60 \mathrm{mg} / \mathrm{dl})$ (Lou et al., 2008). Further, the median leukocytic concentration of copper is $4.0 \%$ higher for PE cases than controls, but this modest difference concerning $\mathrm{Cu}$ did not reach a statistical significance (Mahomed et al., 2000). Also, the increasing $\mathrm{Cu}$ concentrations (as the co-factor of antioxidant enzymes), and oxidant and antioxidant parameters in pre-eclamptic women have shown by some reports. It was suggested that $\mathrm{Cu}$ shows contrary kinetic behavior during the entire pregnancy as compared with the corresponding zinc values (Ilhan et al., 2002; Aksoy et al., 2003 and Atmar et al., 2005). This finding is supported by the decreasing trend in the level of free cortisol that induces the production of $\mathrm{Cu}$-carrying protein among pre-eclamptic women (Kiilholma et al., 1984). As regard the difference between mild and severe pre-eclamptic cases, the mean $\mathrm{Cu}$ in 24-hour maternal urine was higher in mild compared with severe PE cases $(12.92 \pm 3.48$ vs. $11.46 \pm 3.88 \mathrm{mg} / \mathrm{L}$, $\mathrm{P}>0.05$ ) (Ziaei et al., 2008). On the other hand, there are also reports in which maternal serum copper levels were found to be lower in PE as compared to healthy controls (Kiilholma et al., 1984; Mahomed et al., 2000 and Kumru et al., 2003). Maternal serum $\mathrm{Cu}$ level is lower in women with PE compared to healthy controls (Kumru et al., 2003). Further, $\mathrm{Cu}$ level was lower in placental tissues of pre-eclamptic women compared with healthy pregnant women (Acikgoz et al., 2006).
$\mathrm{PE}$ is characterized by increase triglycerides (TGs) and LDL-cholesterol (El-Moselhy et al., 2011). Further, triglycerides favor the formation of LDL. LDL has increased access to the sub endothelial space, where it is sequestered from blood-boom antioxidants. The relevant role of TGs in the genesis of PE is indicted by their being increased long before the manifestation of the disease. Similarly, free fatty acids are increased in PE and this increasement was observed months before the diagnosis of PE (Hubel and Roberts, 1999). Studies indicate that this effect may be secondary to altered $\mathrm{Cu}$ binding by albumin to which large amounts of fatty acids are bound. Unbound copper is a potent stimulator of free radical formation. Ordinarily this effect of copper is prevented by protein binding (primarily, quantitatively to albumin), but albumin binds copper differently when fatty acids are present and copper maintains its ability to participate in redox reactions (Uotila et al., 1998). Thus, increased free fatty acids appear to contribute to oxidative stress. Most of these nutritional mechanisms may be modified by diet, raising the possibility of nutritional prophylaxis of PE (Raijmakers et al., 2004).

Differences in study design, limited statistical power, as well as differences in tissues and analytical techniques used to measure maternal trace elements status are possible explanations for why available studies concerning maternal trace elements status and risk of PE are not in complete agreement. Moreover, differences in population characteristics such as age, race/ethnicity, socio-economic status, as well as country and region of residence may account for some of the variation in results across studies (Mahomed et al., 2000 and Ziaei 2008).

The potential limitations of this study that must be considered is the retrospective design of the study, which was unable to determine whether the observed alterations in calcium and trace elements; copper and zinc concentrations preceded PE or whether alterations attributed to PE. 


\section{CONCLSSIONS AND RECOMM- ENDATIONS}

In this study pre-eclamptic patients had lower mean levels of serum $\mathrm{Ca}, \mathrm{Cu}$ and $\mathrm{Zn}$ compared to pregnant controls with statistically significant differences. Further, they were lower among the severe PE cases compared to mild cases with statistically significant differences. Also, they were significantly correlated with severe PE. The best way to prevent $\mathrm{PE}$ in an effective manner is the establishment of an adequate prenatal control system, whose procedures should contain adequate supplementations with $\mathrm{Ca}$ and trace elements; cu and $\mathrm{Zn}$. In addition, adequate prenatal care would allow physicians to diagnose and promptly treat those with low nutritional intake. Finally, prospective population based studies are needed in different areas in Egypt and on large number of pregnant women to determine possible PE risk factors.

\section{References}

Acikgoz S, Harma M, Harma M, Mungan G, Can $M$ and Demirtas S (2006): Comparison of angiotensin-converting enzyme malonaldehyde, zinc and copper levels in preeclampsia. Biol Trace Element Res, 113(1): 1-8.

Adam B, Malatyaliogu E, Alvur $M$ and Talu C (2001): Magnesium, zinc and iron levels in pre-eclampsia. Maten Fetal Med, 10: 246-50.

Ajayi G (2002): Concentrations of calcium, magnesium copper, zinc and iron during normal and EPH-gestosis pregnancy. Trace Element Med, 10: 151-2.

Aksoy H, Taysi S, Altinkaynak K,Bakan E, Bakan $N$ and Kumtepe $Y$ (2003): Antioxidant potential and transferring, ceruloplasmin, and lip peoxidation levels in women with preeclampsia. J Invest Med; 51 (5): 284-7.

Atallah AN, Hofmeyr GJ and Duley L (2002): Calcium supplementation during pregnancy for preventing hypertensive disorders and related problems. In: The Cochrane Library, Issue 4: CD001059.

Atmar Y, Kocyigit Y, Yokus B, Atmar A and Ceylan A (2005): Lipid peroxidation, antioxidant defense, status of trace metals and leptin levels in preeclampsia. Europ J Obst Gyn Reprod boil, 119: 60-6.

Bassiouni BA, Foda AI and Refai AA (1979): Maternal and fetal plasma zinc in pre-eclampisa. Eur J Obstet Gynecol Reparod Biol, 9: 75-80.
Basso O, Rasmussen S, Weinberg CR, Wilcox AJ, Irgens LM and Skjaerven $R$ (2006): Trends in fetal and infant survival following preeclampsia. JAMA, 296: 1357-62.

Belizan JM and Villar J (1980): The relationship between calcium intake and edema-, proteinuria-, and hypertension-gestosis: A hypothesis. Am J Clin Nutr, 33: 2202-10.

Belizan JM, Villar J and Repke J (1988): The relationship between calcium intake and pregnancy-induced hypertension: Up-to-date evidence. Am J Obst Gynecol, 158: 898-902.

Belizan JM, Villar J, Zalazar A, Rojas L, Chan D and Bryce GF (1983): Preliminary evidence of the effect of calcium supplementation on blood pressure in normal pregnant women. Am J Obst Gynecol, 146: 17580 .

Borella P, Szilagyi A, Than G, Casaba I, Giardlon A and Fachinetti F (2001): Maternal plasma concentrations of magnesium, calcium, zinc and copper in normal and pathological pregnancies. Total Environ, 99: 67-76.

Bower D (2003): The influence of dietary salt intake on pre-eclampsia. Br J Obstet Gynaecol, 63: 123-6.

Bucher HC, Guyatt GH, Cool P and hunt D (1996): Effect of calcium supplementation on pregnancy-induced hypertension and preeclampsia: A meta-analysis of randomized controlled trial. JAMA, 175(14): 1113-7.

Caniggia I, Winter J, Lye SJ, et al. (2000): Oxygen and placental development during the first trimester: implications for the pathophysiology of pre-eclampsia. Placenta, 21: 25-30.

Caughey AB, Stotland NE, Washington AE and Escobar GJ (2005): Maternal ethnicity, paternal ethnicity and parental discordance: Predictors of preeclampsia. Obstet Gynecol, 106: 156-61.

Caulfled LE, Zavaleta N, Shankar AH and Merialdi M (1998): Potential contribution of maternal zinc supplementation during pregnancy to maternal and child survival. Am J Clin Nutr 68: 499S-508S.

Cherry F, Bennett E, Bazzano G, Johnson L, Fosmire $G$ and Batson H (1988): Plasma zinc in hypertension/toxemia and other reproductive variables in adolescent pregnancy. Am J Clin Nutr, 34: 2367-75.

Cherry F, Sandstead H, Rojas P, Johnson L, Batson $H$ and Wang $X$ (1989): Adolescent pregnancy: Associations among body weight, Zinc nurture and pregnancy outcome. Am J Clin Nutr, 50: 945-54.

Chisolm JC and Handorf CR (1985): Zinc, cadmium, metallothionein, and progesterone: Do they participate in etiology of pregnancy induced hypertension? Med Hypotheses, 17: 231-42. 
Crowther C, Hiller J, Pridmore B, Bryce R, Duggan P, Hague WM and Robinson JS (1999): Calcium supplementation in nulliparous women for the prevention of pregnancy-induced hypertension, pre-eclampsia and preterm birth: An Australian randomized trial. Aust N Zealand J Obst Gynaecol, 39: 12-18.

Cunningham FG, Leveno KJ, Bloom SL, Hauth GC, Spong CU and Dwight JR (2010): Text book of Williams' obstetrics- Hypertensive disorder in pregnancy. 23 th Ed, McGraw-Hill, New York.

El-Moselhy EA, Amin HH and Abd El-Aal HM (2011): Amniotic fluid selenium and maternal biochemical findings among preeclamptic women in Cairo, Egypt. J Am Science, in press.

Ehrenberg A (1997): Non-medical prevention of pre-eclampsia. Acta Obstet Gynecol Scan, (Suppl 164): 108-10.

Gromadzinska J, Wasowicz W, Krasomsk G, Broniarczy KD and Andrijewski M (1998): Selenium levels, thiobarbituric acid- reactive substance concentrations and glutathione peroxidase activity in the blood of women with gestosis and imminent premature labour. Analyst, 123: 35-40.

Harma M, Harma M and Kocyigit A (2005): Correlation between maternal plasma homocysteine and zinc levels in preeclamptic women. Boil Trace Elem Res, 104 (2): 97- 105.

Herrera JA, 'Arevalo-Herrera $M$ and Herrera S (1998): Prevention of preeclampsia by linoleic acid and calcium supplementation: A randomized controlled trial. Obstet Gynecol, 91: 585-9.

Hubel CA and Roberts JM (1999): Lipid metabolism and oxidative stress. In Chesley's Hypertensive Disorders in Pregnancy, Lindheimer $\mathrm{M}$, Roberts $\mathrm{J}$ and Cunningham $\mathrm{F}$, (eds.), 2nd Ed., 453-86. Stamford, CT: Appleton $\&$ Lange, New York.

Hunt IF, Murphy NJ, Cleaver AE, Faraji B, Swendseid ME, Browdy BL, Cousloin AH, Dark VA, Settlage RH and Smith JC (1985): Zinc supplementation during pregnancy in lowincome teenagers of Mexican descent: Effects on selected blood constituents and on progress and outcome of pregnancy. Am J Ciln Nutr, 42: 81528.

Ilhan N, Ilhan N and Simsek M (2002): The changes of trace elements, malondialdehyde levels and superoxido dismutase activities in pregnancy with or without preeclampsia. Clin Biochem; 35: 393-7.

Jeyabalan A and Caritis SN (2006): Antioxidants and the prevention of preeclampsia: Unresolved issues. N Engl J Med, 354(17): 1841-3.
Kiilholma PR, Pakarinen $P$ and Gronroos $M$ (1984): Copper and zinc in pre-eclampsia. Acta Obstet Gynecol Scand, 63: 629-31.

Kolusari A, Kurdoglu M, Yildizhan R, Adali E, Edirne T, Cebi A, Demir $H$ and Yoruk (2008): Catalase activity, serum trace element and heavy metal concentrations, and vitamin A, $\mathrm{D}$ and $\mathrm{E}$ levels in Pre-eclampsia. J International Med Res, 36: 1335-41.

Kumru S, Aydin S, Simsek M, Sahin K, Yaman $M$ and Ay G (2003): Comparison of serum copper, zinc, calcium and magnesium levels in preeclamptic and healthy pregnant women. Boil Trace Elem Res, 94: 105-12.

LaMarca BD, Gilbert $J$ and Granger JP (2008): Recent progress toward the understanding of the pathophysiology of hypertension during preeclampsia. Hypertension, 51(4): 982-8.

Lazebnik N, Kuhnert BR and Kulmert PM (1989): Zinc, cadmium, and hypertension in parturient women. Am J Obstet Gynecol, 161: 437-40.

Levine RJ, Hauth JC, Curet LB, Sibai BM, Catalano PM, Morris CD, DeSimonian R, Esterlitz JR, Raymond EG, Bild DE, Clemens JD and Cutler JA (1997): Trial of calcium to prevent pre-eclampsia. N Engl J Med, 337: 6976.

López-Jaramillo P (2000): Calcium, nitric oxide and preeclampsia. Seminars in Perinatology, 24: 33-6.

Lorenz K (1982): Improved determination of serum calcium with o-cresolphthalein complexone. Clin Chem Acta, 126: 327-81.

Lou SG, Amirabi A, Yazidian and Pashhapour (2008): Evaluation of serum calcium, magnesium, copper and Zinc levels in women with preeclampsia. IJMS, 33(4): 231-4.

Mahaba HM, El-Taweel RM and Hafez AS (2001): Dietary pattern and nutritional status in preeclampsia. Egypt J Comm Med, 19 (3): 1-8.

Mahomed K, Williams MA, Woelk GB, Jenkins-Welk L, Mudzamiri S, Madzime S and Sorensen TK (1998): Risk factors for preeclampsia among Zimbabwean women: Recurrence risk and familial tendency towards hypertension. J Obst Gynecol, 18 (3): 218-22.

Mahomed K, Williams MA, Woelk GB, Mudzamiri S, Madzime S, King IB and Bankson DD (2000): Leukocyte selenium, zinc, and copper concentrations in pre-eclamptic and normotensive pregnant women. Biol Trace Elem Res, 75: 107-18.

Mason KE (1979): Copper metabolism and requirements of man. J Nutr, 109: 79-82.

Mikhail MS, Anyaegbunam A, Garfinkel D, Palan PR, Basu J and Romney SL (1994): Preeclampsia and antioxidant nutrients: Decreased plasma levels of reduced ascorbic 
acid, alpha-tocopherol, and beta-carotene in women with preeclampsia. Am J Obst Gynecol, 171: 150-7.

Morris CD, Jacobson SL, Anand R, Ewell MG, Hauth JC, Curet LB, Catalano PM, Sibai BM and Levine RJ (2001): Nutrient intake and hypertensive disorders of pregnancy: Evidence from a large prospective cohort. Am J Obst Gynecol, 184: 643-51.

Moutquin JM, Garner PR and Burrows RF (1997): Report of the Canadian Hypertension Society Consensus Conference: 2. Nonpharmacologic management and prevention of hypertensive disorders in pregnancy. CMAJ, 157: 907-19.

National Education program Working Group on High Blood Pressure (2000): Report on High blood pressure in pregnancy. Am J Obst Gynecol, 183: SI-S22.

Powers RW, Evans RW, Majors AK, Ojimba JI, Ness RB, Crmbleholrne WR and Roberts JM (1998): Plasma homocysteine concentration is increased in preeclampsia and is associated with evidence of endothelial activation. Am J Obstet Gynec, 179: 1605-11.

Prema K (2002): Predictive value of serum copper and zinc in normal and abnormal pregnancy. Indian J Med Res, 71: 554-60.

Pipkin-Broughton F, Carowther C, De-Swelt M, Duley L, Judd A and Liford RJ (1996): Where next for prophylaxis against preeclampsia. Br J Obstet Gynecol, 153: 603- 7.

Raijmakers MTM, Dechend $\mathbf{R}$ and Poston $\mathbf{L}$ (2004): Oxidative stress and pre-eclampsia: Rationale for antioxidant clinical trials. Hypertension, 44: 374-80.

Rayman MP (2000): The importance of selenium to human heath. Lancet, 356: 233-41.

Rayman MP, Abou-Shakra FR, Ward NI and Redman CW (1996): Comparison of selenium levels in pre-eclamptic and normal pregnancies. Biol Trace Elem Res, 55: 9-20.

Roberts JM, Balk JL, Bodnar LM, Belizán JM, Bergel $E$ and Martinez A (2003): Nutrition as a preventive strategy against adverse pregnancy outcomes: Nutrient involvement in pre-eclampsia. J Nutr, 133: 1684S-92S.

Roberts JM and Hubel CA (1999): Is oxidative stress the link in the tow-stage model of preeclampsia? Lancet 354:789.

Rumiris D, Purwosunu Y, Wibowo N, et al. (2006): Lower rate of pre-eclampsia after antioxidant supplementation in pregnant women with low antioxidant status. Hypertens Pregnancy, 25: 241-53.

Sanchez-Ramos L, Sandioni S and Andren FJ (1991): Calcium excretion in pre-eclampsia. Obstet Gynecol, 77: 510-3.

Serdar Z, Gur E and Develioflu O (2006):
Serum iron and copper status and oxidative sress in severe and mild pre-eclampsia. Cell Biochem Func, 24: 209-15.

Skjaerven R, Wilcox A and Lie RT (2002): The interval between prebnancies and the risk of preeclampsia. N Engl J Med, 346: 33-8.

Solmon CG and Seely EW (2004): Preeclampsia: Searching for the cause. N Engl J Med, 350: 641-2.

Sunderman FW Jr (1973): Atomic absorption spectrophotometry of trace elements in clinical pathology. Hum Pathol, 4: 549-50.

Takacs P, Kauma SW, Sholley MM, Walsh SW, Dinsmoor MJ and Green $K$ (2001): Increased circulating lipid peroxides in severe preeclampsia activate NF-kappa $\mathrm{B}$ and upregulate ICAM-1 in vascular endothelial cells. FASEB J, 15: 279-81.

Uotila JT, Solakivi T, Jaakkola I, Tuimala R and lehtimaki $T$ (1998): Antibodies against copper-oxidised and malondialdehyde-modified low density lipoproteins in pre-eclmpsia pregnancies. Br J Obstet Gynaecol, 105:113-7.

Ventura SJ, Martin JA, Curtin SC, Mathews TJ and Park MME (2000): Births final data for 2000- National Vital statistics Reports. Hyattsville National Center Health Statistics, 48(3): 122-5.

Villar J, Merialdi M, Gulmezoglu AM, Abalos E, Carroli G, Kulier R and deOnis M (2003): Nutritional interventions during pregnancy for the prevention or treatment of maternal morbidity and preterm delivery: An overview of randomized controlled trials. J Nutr, 133: 1606S$25 \mathrm{~S}$.

Walsh SW (1998): Maternal-placental interactions of oxidative stress and antioxidants in pre-eclampsia. Semin Reprod Endocrinol, 16: 93-104.

Wang Y and Walsh SW (1996): Antioxidenat activities and mRNA expression of superoxide dismisse, catalase and glutathione peroxidase in normal and pre-eclamptic placentas. J Society Gynecol Investig, 3 (4): 179-84.

Witztum J (1994): The oxidation hypothesis of atherosclerosis. Lancet, 344-793.

Zhao F (1989): $\mathrm{Ca}, \mathrm{Mg}, \mathrm{Cu}$ and $\mathrm{Zn}$ contents of the maternal and umbilical cord serum in pregnancy-induced hypertension. Zhonghua $\mathrm{Fu}$ Chan Za Zhi, 24: 212-4.

Ziaei S, Khayyati Motlagh Bonab SH and Kazemnejad A (2006): Serum lipid levels at 2832 weeks gestation and hypertensive disorders. Hypertens Preg, 25(1): 3-10.

Ziaei S, Ranjkesh $F$ and Faghihzadeh $S$ (2008): Evaluation of 24-hour urine copper in preeclampsia vs. normotensive pregnant and non-pregnant women. Internat J Fertil Steril, 2(1): 9-12. 
Table (1): Means and standard deviations of pre-eclampsia (PE) cases and control group according to the laboratory results of maternal serum calcium and trace elements copper $\&$ zinc biochemical markers.

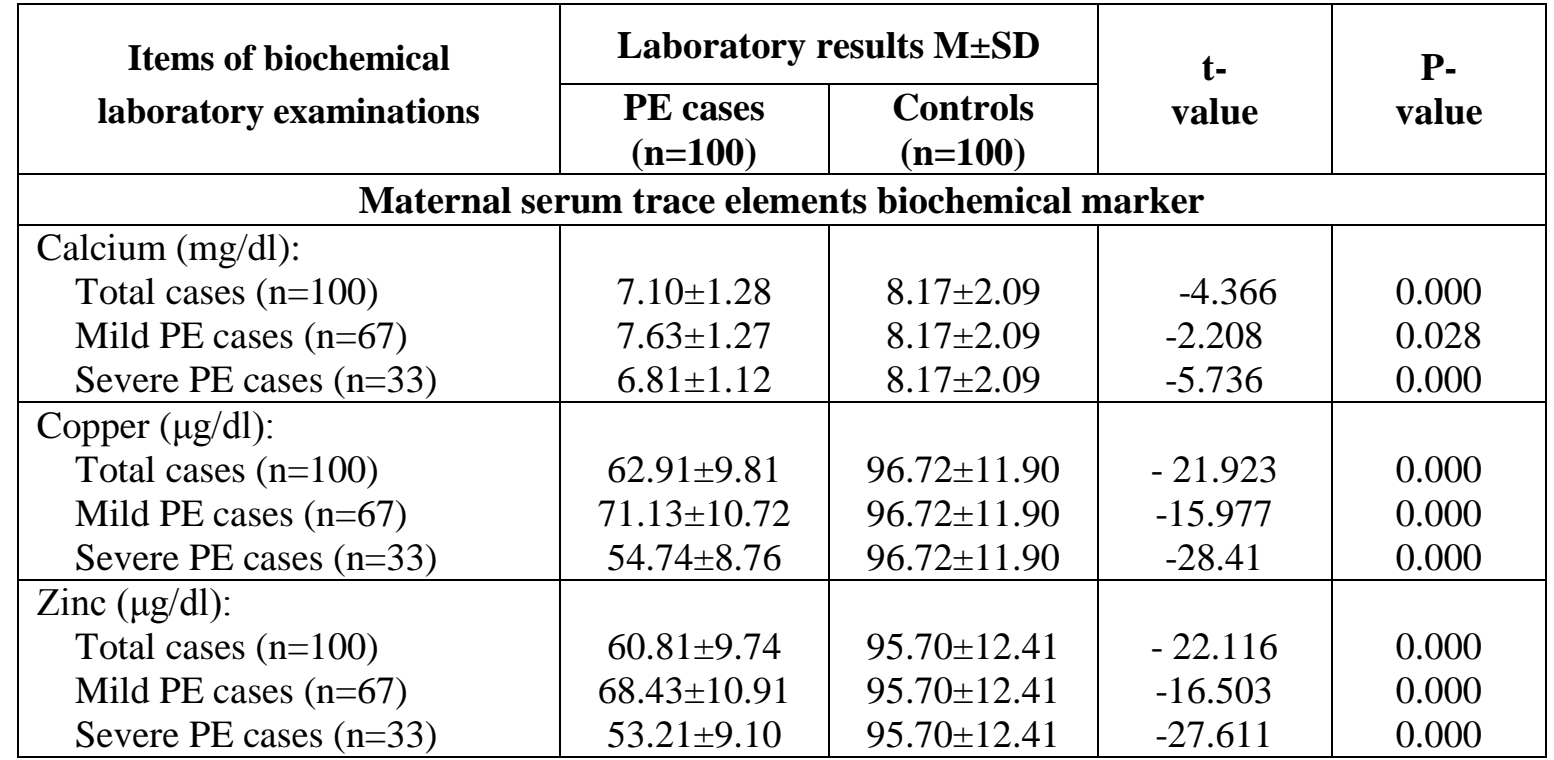

Table (2): Means and standard deviations of the laboratory results of the maternal serum calcium and trace elements copper \& zinc biochemical markers in pre-eclampsia (PE) cases according to severity.

\begin{tabular}{|c|c|c|c|c|}
\hline \multirow{2}{*}{$\begin{array}{l}\text { Items of biochemical } \\
\text { laboratory examinations }\end{array}$} & \multicolumn{2}{|c|}{ Laboratory results $\mathrm{M} \pm \mathrm{SD}$} & \multirow{2}{*}{$\begin{array}{c}\text { t- } \\
\text { value }\end{array}$} & \multirow{2}{*}{$\begin{array}{c}P- \\
\text { value }\end{array}$} \\
\hline & $\begin{array}{c}\text { Mild cases } \\
(n=67)\end{array}$ & $\begin{array}{c}\text { Severe cases } \\
(n=33)\end{array}$ & & \\
\hline \multicolumn{5}{|c|}{ Maternal serum trace elements biochemical marker } \\
\hline Calcium (mg/dl) & $7.63 \pm 1.27$ & $6.81 \pm 1.12$ & 3.291 & 0.002 \\
\hline Copper $(\mu \mathrm{g} / \mathrm{dl})$ & $71.13 \pm 10.72$ & $54.74 \pm 8.76$ & 8.154 & 0.000 \\
\hline Zinc $(\mu \mathrm{g} / \mathrm{dl})$ & $68.43 \pm 10.91$ & $53.21 \pm 9.10$ & 7.352 & 0.000 \\
\hline
\end{tabular}

Table (3): Correlation co-efficient of severe pre-eclampsia (PE) cases according to significant results of the laboratory examinations of maternal serum.

\begin{tabular}{|l|c|c|}
\hline $\begin{array}{c}\text { Items of biochemical } \\
\text { laboratory examinations }\end{array}$ & $\begin{array}{c}\text { r- } \\
\text { value }\end{array}$ & $\begin{array}{c}\text { P- } \\
\text { value }\end{array}$ \\
\hline Calcium $(\mathrm{mg} / \mathrm{dl})$ & 15.276 & 0.01 \\
\hline Copper $(\mathrm{mg} / \mathrm{dl})$ & 12.49 & 0.03 \\
\hline Zinc $(\mathrm{mg} / \mathrm{dl})$ & 8.12 & 0.01 \\
\hline
\end{tabular}


دراسة مستوى الكالسيوم وبعض العناصر المعدنية النادرة (النحاس و الزنكل) فى مصل الدام

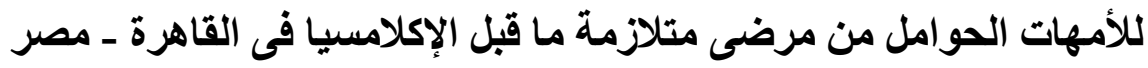

عصام عبد المنعم المصيلحى ـ هشام حمدى أمين*_. هانى ماجد عبد العال***

\author{
أقسام

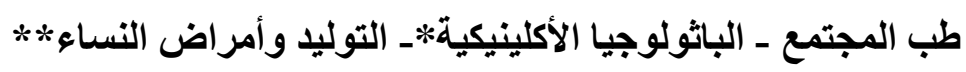 \\ كلية الطب - جامعة الأزهر
}

تُعتبر متلازمة ما قبل الإكلامسيا واحداً من الأمر اض ذات الأسباب المتعددة والتى تصيب كثيرَ

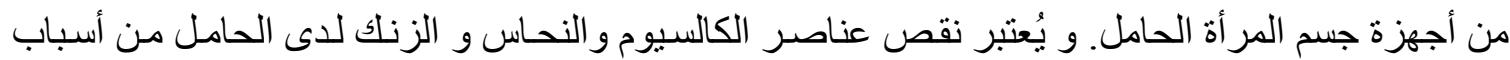

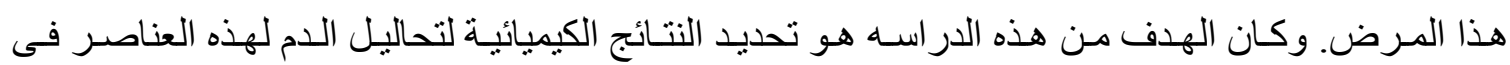

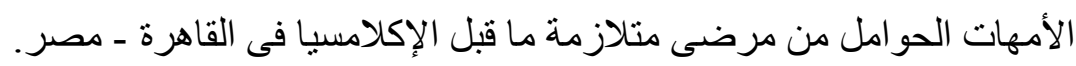

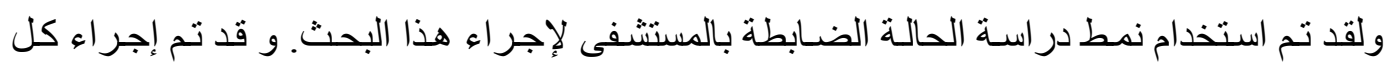
الفحوص المعملية اللازمة لكلا المجمو عتين.

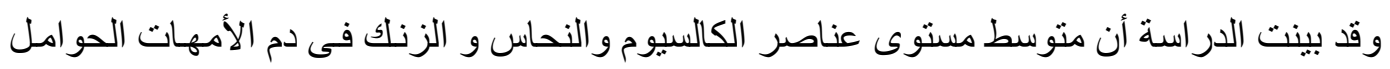

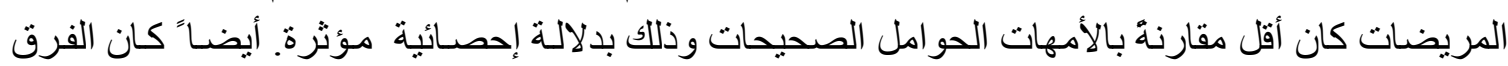

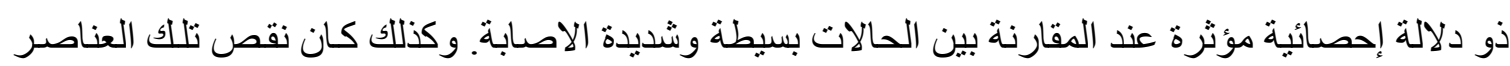

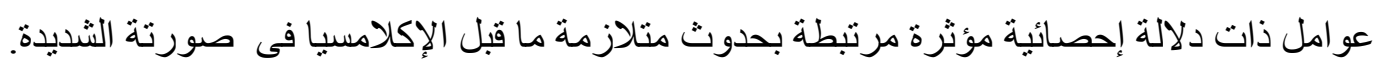

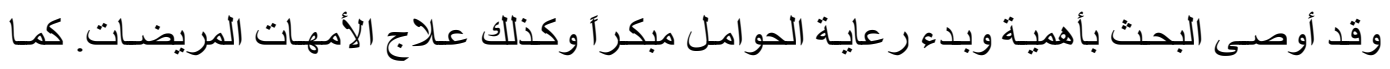

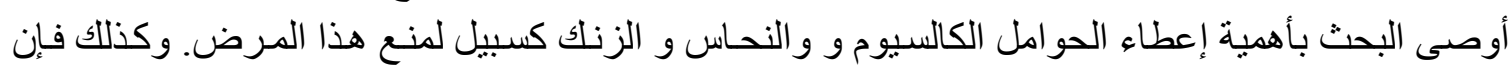

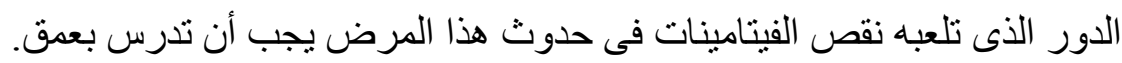

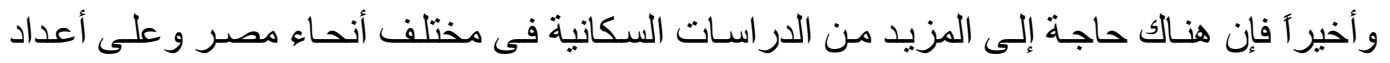

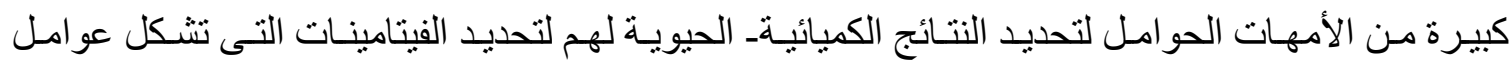
خطورة لهذا المرض الأهر ال 